\title{
Not so Different Altogether: Putting Lean and Sociotechnical Design into Practice in a Process Industry
}

\author{
Torbjørn Hekneby ${ }^{1}$ (D) , Jos Benders ${ }^{2,3}$ (D), Jonas A. Ingvaldsen² (iD \\ ${ }^{1}$ Department of Strategy and Management, University of Agder, School of Business and Law (Norway) \\ ${ }^{2}$ Department of Industrial Economics and Technology Management, Norwegian University of Science and Technology (NTNU) \\ (Norway) \\ ${ }^{3}$ Centre for Sociological Research (CESO), KU Lewven (Belgium) \\ torbjorn@storform.no,jos.benders@ntnu.no,jonas.a.ingvaldsen@ntnu.no
}

Received: August 2020

Accepted: December 2020

\begin{abstract}
:
Purpose: The shop-floor organization under lean production (LP) has been hotly debated for about three decades. As this organization concept leaves considerable room for interpretation, the content of lean-inspired changes can vary widely. This paper pleads for a contingency view of how LP is implemented and how the outcomes of lean-inspired changes rely on users' interpretations of the concept in particular production contexts.
\end{abstract}

Design/methodology/approach: A case study was conducted in two large Norwegian chemical plants. Data from the observations and interviews were supplemented by interviews with top managers in 2017 and 2018. The first author also followed a management audit in one plant, assessing the plant's overall implementation of the company-specific production system.

Findings: The lean-inspired changes in the company had brought about a shop-floor organization typically associated with sociotechnical design (STD), including extensive employee choice autonomy and a broad span of control.

Originality/value: Our findings demonstrate the importance of understanding how lean is interpreted in different contexts. Our contingency view may aid organizational designers in making more-informed choices by clarifying relevant issues and trade-offs in lean implementations.

Keywords: lean production, contingency theory, organization concepts, sociotechnical design

\section{To cite this article:}

Hekneby, T., Benders, J., \& Ingvaldsen, J.A. (2021). Not so different altogether: Putting lean and sociotechnical design into practice in a process industry. Journal of Industrial Engineering and Management, 14(2), 219-230. https://doi.org/10.3926/jiem.1537

\section{Introduction}

Ever since the concept of lean production (LP) was launched in the late 1980s (Krafcik, 1988; Womack, Jones \& Roos, 1990), researchers have debated the type of shop-floor organization that lean-inspired changes give — and should give — rise to (e.g. Delbridge, Lowe \& Oliver, 2000; Mehta \& Shah, 2005; Hopp, 2018). The superior performance of Japanese-owned plants was the obvious trigger for management scholars and practitioners to pay attention to LP. The crux, of course, is whether emulators of LP have succeeded in achieving performance 
improvements. This issue has been the subject of considerable empirical research. In a recent review, Cocca, Marciano, Alberti and Schiavini (2018) even identified as many as 31 different measurements for so-called 'leanness' and associated performance outcomes.

It could be argued that the concept of lean, more than other organization concepts, leaves considerable room for interpretation. This room for interpretation means that users intentionally or unintentionally select components that they find suitable to their own context (Benders, van Grinsven \& Ingvaldsen, 2019). The resulting shop-floor organization is thus a function of two interdependent dimensions:

1. The organizational context

2. Users' interpretations of lean

Hence, we call for situated and contingent understandings of lean-inspired changes (Marin-Garcia \& Bonavia, 2015; Sousa \& Voss, 2008). Different organizational forms will emerge depending on how lean is implemented, which will have either negative or positive consequences for performance (Hopp, 2018; Marin-Garcia \& Bonavia, 2015). This may explain why LP has been, still is and will remain hotly debated.

To concretize these rather abstract statements, we present a case study of how LP has been implemented in two large Norwegian chemical plants. Operational processes in the process industries are markedly different from those in car manufacturing, where LP was developed and refined (Marin-Garcia \& Bonavia, 2015). Whereas Toyota perfected the repetitive and convergent manufacturing of discrete products (Young, 1992), most process industries are characterized by divergent and continuous product flows, monitored by process operators. In this context, we find that lean-inspired changes may result in an organizational design that closely resembles one that might have been proposed by proponents of sociotechnical design (STD) (Achterbergh \& Vriens, 2010; Mohr \& van Amelsvoort, 2016). This is remarkable, given that LP and STD are often viewed as opposing approaches (Berggren, 1992; Dabhilkar \& Åhlström, 2013; Dankbaar, 1997; Pil \& Fujimoto, 2007; Oudhuis \& Tengblad, 2020).

This paper is structured as follows. First, we discuss lean as an organization concept and argue that it lends itself to different interpretations. Next, we discuss how scholars have dealt with the significance of different production contexts and present a framework for assessing organizational outcomes. After presenting our methodology and the case study, we present some implications of our contingency view for the outcomes of LP, as well as under what circumstances lean-inspired changes lead to results similar to those of STD-inspired changes. We conclude by proposing implications for industrial engineers and managers.

\section{Lean as an Organization Concept}

An organization concept consists of prescriptive notions on how to manage or organize, which are meant for consumption by managers and are known by a particular label (Benders \& Verlaar, 2003). They are characterized by what we call 'interpretative viability' (Ortmann, 1995): for ideas to be disseminated at a large scale, they must appeal to different parties, each of which can interpret the ideas in their own way. Room for interpretation is thus essential for an idea to diffuse. At the same time, this room for interpretation means that academics tend to criticize concepts as being ambiguous.

This is particularly true for lean. In order to understand how this notion has come about, we need a concise description of its evolution as an organization concept. Using comparative performance data of passenger car plants in Japan, the USA, and Europe, Krafcik (1988) showed that the Japanese-owned plants performed better, irrespective of their location. This message was popularized by Womack et al. (1990). The notion that significant performance improvements could be achieved only if LP was adopted came at the right moment, as it was introduced at the beginning of a global economic recession. Obviously, it was only possible to conduct the underlying research because many plants were 'lean' prior to the launch of this label. The production system that was to become known as 'lean production' had been developed within Toyota Motors (Fujimoto, 1999; Holweg, 2007; Liker, 2004; Ohno, 1988), and many publications had appeared prior to 1988 (e.g. Schonberger, 1982; Shingo, 1981; Sugimori, Kusunoki, Cho \& Uchikawa, 1977). All of these focused on convergent repetitive manufacturing: assembling many components into large numbers of discrete products, namely cars. 
Womack and Jones (1996) brought the discussion to a higher level of abstraction. Whereas the authors asserted that their first book had shown how well LP worked, the aim of their next book was to focus on how those results had been attained. Observing that many practitioners struggled with the implementation of specific methods, they argued in favor of a publication on the larger system within which these methods fitted. Here, they launched the term 'lean thinking', which has five key principles:

1. Specify customer value by specific product

2. Identify the value stream for every product

3. Create an uninterrupted value stream per product

4. Let the customer pull value

5. Pursue perfection (by improving constantly)

This opened the door for applying these ideas well beyond the domain in which the Toyota Production System had been developed. Over the past decades, many Japanese (Nielsen, Møller \& Koch, 1990) and lean-inspired changes have been reported in various types of manufacturing and service industries (Leite, Radnor \& Bateman, 2020; Netland \& Powell, 2017).

One specific way of disseminating lean is to develop a 'company-specific production system' (Hekneby, Ingvaldsen \& Benders, 2020; Netland, 2013). Companies have tried to emulate Toyota's success by modeling their own versions of the Toyota Production System, thereby drawing on the original model while adding their own twists. This has involved adapting it to their own situations and distinctiveness, using their own interpretations of the Toyota Production System, and incorporating elements from other organization concepts.

\section{The Influence of Context: Types of Production}

A classic insight in organization studies is that the type, range, volume, and variability of manufactured products are closely related to organizational forms and production technologies (Donaldson, 2001; Hull \& Collins, 1987; Woodward, 1980). This so-called contingency view holds that different output characteristics and production technologies give rise to different managerial problems and solutions and that a good fit between the production technology and organizational design leads to better performance (Mintzberg, 1980; Sorge, 1991; Sousa \& Voss, 2008). Based on the contingency view, it follows that the application of prescriptive concepts such as LP results in different forms of organizations in different production contexts (Sousa \& Voss, 2008).

Several typologies have been proposed for the classification of production systems. Woodward's (1980) original classification included batch, mass, and continuous-process production. Hull and Collins (1987) refined this typology by distinguishing between traditional batch production and more R\&D-intensive technical batch production. A more common model for operations management is the product-process matrix of Hayes and Wheelwright (1979), which suggests that the primary technological process of a manufacturer can be classified as jumbled flow (job shop), disconnected line flow (batch), connected line flow (assembly line), or continuous flow (Safizadeh, Ritzman, Sharma \& Wood, 1996).

When applied to the industries in the study, it follows that automotive firms tend to be organized differently from process industries, as the nature of their output and production processes differs substantially. Lean was developed, and most intensely discussed, with respect to the final assembly lines of passenger car factories (e.g. Berggren, 1992). Its very essence is to bring together many different components into one final product. The work performed is characterized by a high degree of repetitiveness and tightly coordinated production, leaving little room for employee choice autonomy (de Treville \& Antonakis, 2006). In contrast, most work in process industries consists of monitoring production processes, which take place in vessels. This generally requires a high level of formal skills, as well as practical experience with the processes at hand (Kern \& Schumann, 1992). Unlike the situation in final assembly in the automotive industry, there is little manual work involved.

\section{The Lean-STD Debates}

To determine more precisely how lean-inspired changes may lead to the counter-intuitive result of an organizational structure that fits STD-prescriptions, we need a framework that lists the key differences between the organizational forms conventionally brought about by applying the two concepts. Based on the debates of the 1990s, we can 
identify three main contested issues for shop-floor organization (Adler \& Cole, 1993; Benders \& Van Hootegem, 1999; Berggren, 1992; Dankbaar, 1997; Leite et al., 2020; Niepce \& Molleman, 1998; Pil \& Fujimoto, 2007). These issues are listed in Table 1.

\begin{tabular}{|l|l|l|}
\hline \multicolumn{1}{|c|}{ Aspect of design } & \multicolumn{1}{c|}{ LP } & \multicolumn{1}{c|}{ STD } \\
\hline Strength of coupling & $\begin{array}{l}\text { Sequential activities are tightly coupled } \\
\text { and closely interdependent }\end{array}$ & $\begin{array}{l}\text { Segmenting the production line into units, } \\
\text { separated by buffers }\end{array}$ \\
\hline Focus of employee autonomy & $\begin{array}{l}\text { Responsible autonomy (continuous } \\
\text { improvement by means of standard } \\
\text { operating procedures (SOPs)) }\end{array}$ & $\begin{array}{l}\text { Choice autonomy (minimum critical } \\
\text { specification) }\end{array}$ \\
\hline Width of supervisory spans & Narrow & Broad \\
\hline
\end{tabular}

Table 1. Contested issues in the LP-STD debates

The first issue concerns how tightly sequential operations are coupled. While both lean and STD are strongly in favor of creating production flows (Christis \& Soepenberg, 2016), they disagree on the internal organization of these flows. LP's just-in-time principle makes sequential activities tightly coupled and thus closely interdependent. This is thought to increase the speed of material flows, reduce work-in-process inventories, and enable the rapid detection of quality problems so that they may be resolved immediately (Ohno, 1988). The sociotechnical perspective stresses that such tight coupling causes disturbances that will be felt throughout the production system. To prevent this, the perspective prescribes segmenting a production line into units that are separated by buffers (de Sitter, Hertog \& Dankbaar, 1997; Pil \& Fujimoto, 2007).

The second issue involves employee autonomy and the role of SOPs. From an LP perspective, standards for work execution codify best practice and can—and should—be systematically refined through continuous improvement activities (Adler \& Cole, 1993; Marin-Garcia \& Bonavia, 2015). From an STD perspective, standardization going beyond basic coordination needs contradicts the principle of 'minimum critical specification': specifying only in detail that which needs to be specified (Cherns, 1976). When the foundations of sociotechnical theory were laid during the 1950s and 1960s, SOPs were normally written by industrial engineers at staff offices, with minor involvement and participation of the employees executing the SOPs. This 'scientific management' approach resulted in negative work conditions on the shop-floor level (Mohr \& van Amelsvoort, 2016). Sociotechnical designers recommend letting the employees choose their work methods, as they knew best what worked in their own situations (Marin-Garcia\& Bonavia, 2015; Mehta \& Shah, 2005). De Treville and Antonakis (2006) labeled these differences 'responsible autonomy' versus 'choice autonomy', prescribed by lean and STD, respectively.

The third issue is the nature of supervision. Although lean is widely associated with flat organizational structures (e.g. Karlsson \& Åhlström, 1996), empirical research on plants with detailed knowledge of the Toyota Production System has indicated that these are characterized by narrow spans of control, with work unit leaders occupying strong positions of formal and informal power (Delbridge et al., 2000; Inamizu, Fukuzawa, Fujimoto, Shintaku \& Suzuki, 2014; Ingvaldsen \& Benders, 2016). Ingvaldsen and Benders (2016) argued that such arrangements are functional for the just-in-time production process, as supervisors handle coordination, coach workers, facilitate improvement activities, and form a buffer of manpower in the event of production disturbances. Furthermore, supervisors should act as 'benevolent fathers', educating workers but also disciplining them when necessary (Dore, 1973). In contrast, STD —at least in the more-radical and anti-hierarchical manifestations (e.g. Herbst, 1976)— prefers leaderless teams, as leaders are seen as fundamentally undemocratic and may slow down decision-making.

It is noteworthy that all three issues relate directly to the most contested topic in the LP-STD debates: LP's effects on the quality of working life (QWL) (Benders, Bal \& Vermeerbergen, 2019; Carter, Danford, Howcroft, Richardson, Smith \& Taylor, 2017; Hasle, 2014; Marin-Garcia \& Bonavia, 2015; Neirotti, 2020; Procter \& Radnor, 2017). In conventional models for QWL, autonomy is seen as a predictor of worker well-being (Schouteten \& Benders, 2004; De Treville \& Antonakis, 2006). Just-in-time and SOPs reduce workers' discretion regarding timing and methods for task execution, respectively. A strong supervisory position may potentially limit workers' decision 
latitude over a wide range of aspects. Hence, workers may experience a poorer QWL than would have been the case if STD prescriptions for choice autonomy had been observed.

\section{Data and Methods}

Elkem ASA is a Norwegian company with Chinese owners (from 2011) and operations worldwide. Twenty years ago, Elkem began to develop and implement its business system built on LP, heavily influenced by Scandinavian working life traditions (Ingvaldsen, 2013). Elkem was selected because it represents an ideal case for exploring a company's implementation of LP in a process industry context.

All data were collected by the first author in spring and autumn 2017 and winter 2018. Table 2 describes the data in detail. The observations and interviews from two Norwegian plants were supplemented by interviews with top managers and managers responsible for the implementation of Elkem's business system. The first author also followed a management audit in one plant, assessing the plant's overall implementation of the company's business system. All interviews were recorded and later transcribed. The first author conducted observations during day, afternoon, and night shifts at the plants' furnaces. He also observed continuous improvement meetings and management meetings. All observations were summarized and transcribed into files. Note that data were collected via various methods in order to avoid single source bias.

The data were analyzed and interpreted by all authors in a number of consecutive discussion rounds. The starting point for the data analysis was to map and understand the logic of Elkem's business system, based on the interviews with top managers and division managers, as well as the audit program. The observations and interviews were then coded to determine how the business system was put into practice at the plants. We systematically looked for organizational and technological choices influencing the contested issues in the LP-STD debates (see Table 1) and the resulting organizational outcomes. Findings from the interviews, observations, and collected data were systematically triangulated to improve the internal validity, as recommended by Yin (2009). To further strengthen the validity, we used participant verification by encouraging groups of key informants to comment on our findings.

\begin{tabular}{|c|c|c|c|c|}
\hline Unit of enquiry & $\begin{array}{c}\text { Management } \\
\text { interviews }\end{array}$ & $\begin{array}{c}\text { Shop-floor } \\
\text { interviews }\end{array}$ & Observations & Archival data \\
\hline Plant 1 & 9 managers & 8 operators & $\begin{array}{c}5 \text { days on the shop floor, both day } \\
\text { and night shifts }\end{array}$ & Plant performance \\
\hline Plant 2 & 7 managers & 7 operators & $\begin{array}{c}4 \text { days on the shop floor, both day } \\
\text { and night shifts }\end{array}$ & Plant performance \\
\hline Top management & 4 managers & N/A & N/A & Elkem performance \\
\hline $\begin{array}{c}\text { Implementation } \\
\text { audit }\end{array}$ & 4 managers & N/A & 4 days following the audit & $\begin{array}{c}\text { Plant implementation } \\
\text { performance }\end{array}$ \\
\hline
\end{tabular}

Table 2. Data material

\section{Findings}

We present our findings in this section, beginning with the context of production in Elkem. We then proceed to the organizational outcomes.

\subsection{Context of Production}

The plants produce silicon materials for the global market. The production environment may be classified as a highly automated process, producing large volumes of standardized products. The plants are organized around a single main material flow, which diverges only in the last phases of the value stream. Raw materials (mainly minerals and carbon-based reductants) are automatically transported to the 'furnaces', considered the 'heart of the process'. The furnaces separate the silicon through an electrochemical process. Aided by sensor technology, skilled operators monitor and control critical input, process, and output variables. Based on customer orders, silicon flakes are crunched to different sizes, sorted by quality, and packed for shipping.

A primary strategic focus at Elkem over the last 20 years has been the implementation of a comprehensive business system built on LP principles. Developed in Norway, the business system is also heavily influenced by Norwegian 
working life norms, reflecting the ideas of STD. The business system's main goal is to reduce variability so that processes are 'under control'. To do so, the business system prescribes the application of LP tools (5S, production leveling, Total Productive Maintenance, etc.) and employee empowerment. At Elkem, employee empowerment implies two important organizational choices: first, to show 'respect for people' and involve everyone in continuous problem-solving, and, second, to decentralize decision-making in autonomous work teams and remove the position of the team supervisor. Extensive empowerment is thought to lead to better problem-solving and higher employee motivation. In the words of the CEO:

I bad to understand the [people] dimension and how strong it is. The enormous energy you can release through the organization when people are properly trained and are made responsible... and your decisions are decentralized.

A dual emphasis on improving both technology and human resources is evident in Elkem's concept of 'the double integrated chain of value' (see Figure 1), indicating that technological and human development should be equally emphasized, as specified in the statement: 'To create world-class production, we need world-class operators'. To realize the double chain of value, Elkem has made several investments in technology and people.

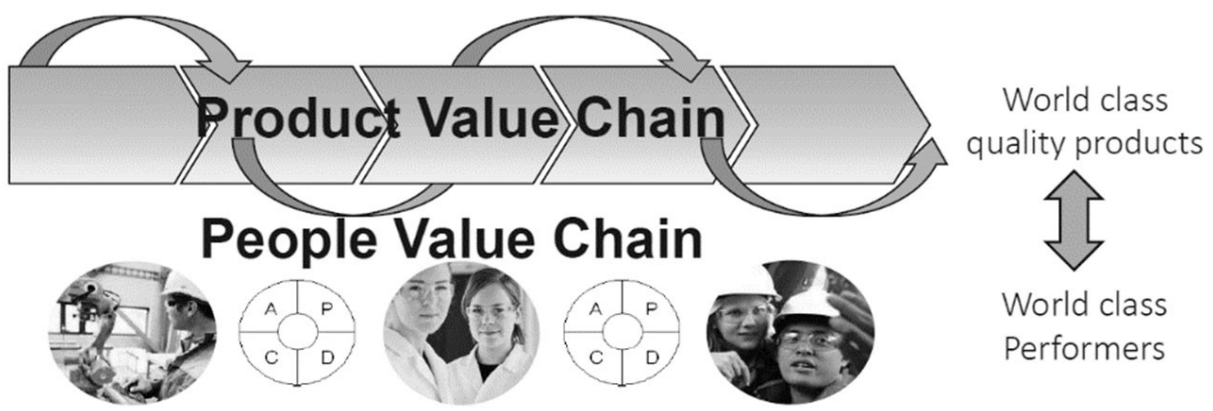

Figure 1. The double integrated chain of value (from a company presentation)

First, the upstream and downstream processes are extensively automated, and transportation of the materials (from the raw materials received at the docks to the final products) is fully integrated in a just-in-time logistics system. The furnaces, which are the production bottlenecks, signal when raw materials are needed, triggering the preparation of new raw materials. The output of the furnaces is stored in 'cooler containers' to reach the right temperature. Based on customer orders, silicon flakes are crunched to different sizes, sorted by quality, and packed for shipping.

Second, the introduction of sensor technology significantly changed the furnace operators' jobs, turning them into highly knowledgeable system controllers (cf. Kern \& Schumann, 1992). When the raw materials hit the furnace, the operators at the furnace have all the input data at hand, using it to adjust the process to ensure a stable output. Temperature, weight of the raw materials, humidity in the raw materials, gas concentration, and electrode levels are all examples of process control data, and these data are shown on large TV screens in the control rooms. Computer-controlled systems are then used to manage the overall process and evaluate statistical data.

Third, Elkem launched a continuous improvement initiative, with extensive operator involvement. At one of the plants visited, 80 out of 105 of the operators had voluntarily participated in 'critical process groups', working systematically to reduce the furnaces' instability. Using the A3 tool from LP, improvement targets, analyses, and hypotheses were worked out and taken back to the operational teams for implementation. The operators reported a strong motivation for this job, stating that the continuous improvement work was one of the most important activities for improving performance at the plant.

Because... you know, if the furnace is good, my job is good. The group work has been very important for my daily work. (Furnace operator)

\subsection{Organizational Outcomes}

Table 3 summarizes the organizational outcomes with respect to the contested issues in the LP-STD debates. Although material flows were organized just-in-time, we observed that the organizational outcomes were similar to the recommendations of STD. 


\begin{tabular}{|l|l|}
\hline \multicolumn{1}{|c|}{ Aspect of design } & \multicolumn{1}{c|}{ Elkem outcome } \\
\hline Strength of coupling & $\begin{array}{l}\text { Material flows were just-in-time, but because of extensive automation, work activities } \\
\text { were not tightly coupled and machine paced }\end{array}$ \\
\hline Focus of employee autonomy & $\begin{array}{l}\text { Operators were primarily left with non-routine regulatory tasks, over which they } \\
\text { enjoyed extensive choice autonomy }\end{array}$ \\
\hline Width of supervisory spans & On the shop floor, there were no supervisors instructing or guiding the workers \\
\hline
\end{tabular}

Table 3. Elkem's shop-floor organization with respect to design aspects

\subsubsection{Strength of Coupling}

As explained above, the material flows at the plants were designed according to the just-in-time principle. However, because of extensive automation, work activities did not become tightly coupled and machine paced, as would be the case in an assembly line. Aside from some routine tasks, task execution was generally triggered by undesirable variations in the chemical processes, not by the arrival of materials to be processed. If the 'furnace was good' (i.e. all process parameters were within the desired range), no action was required by the operators. This meant that as long as things ran smoothly, the work pace was steady and relatively slow. When asked to compare the current furnace process and the process 15 years ago, the operators' first response was often a smile and a statement regarding reduced work intensity:

The most important thing for us is that the furnace works well. Then, everything is more relaxed, and we will have a better shift. Fifteen years ago, the furnace was very unstable, and we had no control of the process and [it was] hard to operate. (Melting plant operator)

\subsubsection{Focus of Employee Autonomy}

At Elkem, the operators' routine tasks were standardized in SOPs. Consistent with an LP work design, the operators had been organized into continuous improvement groups to establish and refine those standards. This introduced an element of responsible autonomy.

However, as routine tasks had largely been automated, operators were primarily left with non-routine regulatory tasks. Observations on the shifts indicated that the operators spent $60-70 \%$ of their time observing and controlling the furnace parameters. Parameters that influenced technical performance were related in non-linear ways, giving rise to complex feedback loops. It was impossible to impose standard regulatory actions for contingencies that might occur in the furnace. Consequently, the operators enjoyed extensive choice autonomy. For instance, the operators might adjust the level of raw material poured into the furnace, based on sensor information on the TV screens and their experience with the furnace. During a shift, some events might call for minor adjustments, and some might call for more-complicated decision-making. Bigger breakdown decisions normally require assistance from a process engineer, but operators generally have the authority to take actions on their own, based on their training and experience:

Twenty-five years ago, we had supervisors on the shift telling us what to do and nothing was left for us to decide. Today, I operate the furnace based on some basic SOPs, but when something happens, nobody controls me or tells me what to do. (Furnace operator)

This logic was also applied to the pouring team in the downstream process. Observations indicated that approximately $30-40 \%$ of the pouring team's tasks were non-routine. They primarily involved observing and adjusting the pouring process when the indicators of level, quality, or pouring stream moved within the upper and lower indicator levels.

\subsubsection{Width of Supervisory Spans}

At Elkem, there was no direct supervision on the shop floor, instructing or guiding the workers to make the right decisions. The operators only contacted the technical specialists when it was determined that their input was needed. In fact, the operators went so far as to say they had 'no important use for management'. They felt capable and confident that they could solve most of the operational tasks on their own. 
It could be several days before I see my team leader. Actually, I don't really need to see him down here, because we are running the furnace on our own. (Furnace operator)

When asked how it worked, not having a leader to follow up their daily work, the operators did not seem to fully comprehend the question. To them, the question was irrelevant because taking necessary actions to stabilize the furnace was considered a team responsibility. The company had invested in formal and informal training to support autonomous decision-making. The relatively slow and steady pace of work meant that coordination needs were modest and less time-critical than for an assembly line. Hence, supervisors' coordination and 'buffer of manpower' functions were not essential for keeping production running. In the interviews with the operators, this team perspective appeared to have resulted in a strong sense of responsibility towards the work process and a highquality working life experience. Quotes from the interviews corroborate this impression:

I have total responsibility for the furnace, and this gives me a very good feeling. If the furnace works well, I work well, and this is very important for my life. (Furnace operator)

I have worked in the pouring room for many years, and I am still very happy with my job. We have a great social community, help each other when needed, and, yes, I love my job. (Pouring operator)

\section{Conclusion and Discussion}

In this article, we have shown how a contingency view, emphasizing users' interpretations of lean in particular production contexts, can advance our understanding of the outcomes of lean-inspired changes. In the case of Elkem, a lean-inspired production system had brought about a shop-floor organization typically associated with STD, including extensive employee choice autonomy. The primary transformation tasks were automated to the extent where just-in-time material flows were realized without leading to repetitive, machine-paced work. SOPs remained in place for routine tasks, but as most tasks were regulatory and non-routine, the company relied on a qualified workforce to make independent decisions. Close supervision had become less important, as there was less need for coordination and the operators were skilled decision-makers.

\subsection{Theoretical Contributions and Research Implications}

The contingency view proposed in this paper has major implications for understanding the outcomes of leaninspired changes. As our case study illustrates, the operational processes in process industries differ in significant ways from those in repetitive and convergent manufacturing. As these process characteristics provide the operational context wherein lean is applied, lean can be put to work quite differently in a process industry than in a company producing large amounts of similar, discrete products. The different uses can also be related to the predominant frames of reference in the national contexts of organizations. More precisely, the way in which lean is connected to employee autonomy in our case was informed by prevailing norms in Norway. At the same time, the process context is ideally suited to this specific interpretation. Such close interdependencies between process characteristics and national characteristics have been outlined before (Lowe, Delbridge \& Oliver, 1997; Sorge, 1991) and illustrate some of the complexities of attributing outcomes to the umbrella concept 'lean'.

Consequently, formulating a general definition of leanness applicable across contexts and cases can only be achieved at a very high level of abstraction. This has also been done in recent attempts to formulate the essence of lean (Cocca et al., 2018; Netland \& Powell, 2017). Another implication from our argument is that searching for stable statistical relationships between 'leanness' and specific outcomes will likely give inconclusive or weak results, even if there is a consensus on the general definition of lean. More reliable findings may be produced if the nature of the production context is taken into account, for instance by using the classification schema of Hayes and Wheelwright (1979) or Hull and Collins (1987). Nevertheless, selective interpretations of the concept (Benders \& Slomp, 2009; Spring \& Unterhitzenberger, 2020) indicate that outcomes are always situated in concrete contexts, which can only be somewhat accounted for in survey-based research.

Our contingency view may inform debates on the relationship between LP and STD (e.g. Marin-Garcia \& Bonavia, 2015). With few exceptions (e.g. Benders \& Van Hootegem, 1999), prior studies on the LP-STD relationship have had little to say about technical contingencies and have implicitly assumed that the findings from a particular environment (e.g. convergent mass production) may be generalized. In convergent mass production, applications of 
the two concepts have led to different outcomes, as their different preferences for coupling activities, prescribing task execution, and supervision have been accentuated (Adler \& Cole, 1993; Berggren, 1993; Dankbaar, 1997; Niepce \& Molleman, 1998; Pil \& Fujimoto, 2007). As shown in this case study, however, process production is a different story. Here, a lean-inspired production system had brought about outcomes typically associated with STD. The Elkem case study lends some support to the idea that LP and STD can be made compatible, with 'no inherent conflict' (Dabhilkar \& Åhlström, 2013: page 1019). However, the contingency view indicates that we should show great caution in drawing conceptual interferences from empirical findings, as suggested by Dabhilkar and Åhlström (2013) and Pil and Fujimoto (2007). Whether or not the concepts themselves can be seen as compatible at a conceptual level also depends on how the concepts are defined. This implies some arbitrariness, especially in terms of the fairly ambiguous concept 'lean', where multiple definitions and measures coexist in the literature (Cocca et al., 2018). Whether or not applications of the concepts bring about similar outcomes is, at an empirical level, an issue of how they are put to use in concrete contexts.

With respect to the relationship between LP and QWL, we suggest that future research should take into account the differences in production environments. Although literature on the LP-QWL relationship has shifted towards contingency models (Hasle, 2014; Huo \& Boxall, 2018), the contingency factors highlighted have been social (e.g. industrial relations, process of implementation, and employee involvement) rather than technological. Situating findings within specific production environments might lead researchers to discover more robust empirical relationships.

Future research might further develop a contingency model of the LP-STD relationship by investigating production contexts that have not been discussed here, such as job shops and batch production, and testing our findings on larger samples though surveys or comparative case studies. Based on our findings, we hypothesize that applying LP and STD tends to bring about similar outcomes when 1) the level of automation is high and 2) tasks are predominantly nonroutine as opposed to routine. On one hand, these two variables often go together, as routine tasks are more likely to be automated, leaving operators with non-routine tasks. On the other hand, a high ratio of non-routine tasks may also be present in less-automated environments, for instance in one-of-a-kind production.

\subsection{Managerial Implications}

Our findings have clear managerial implications. Designing production systems means making choices, and these choices are made by managers and industrial engineers. Where our contingency view highlights key factors in the environment of these organizational designers, for the latter these are the conditions within which they make decisions. These decisions can be divided into two main categories:

1. selecting and combining relevant insights from organization concepts;

2. making them fit for the specific context to be (re)designed.

The contingency model may aid managers and industrial engineers in making more informed choices by clarifying the issues and trade-offs involved in prescribing a production system. Our model especially questions the widely held notion that there is a trade-off between swift material flows and workers' choice autonomy. This idea emerged from the LP-STD debates of the 1990s (e.g. Berggren, 1992; Dankbaar, 1997). While this certainly holds historically for the case of repetitive convergent manufacturing, it hardly applies to the context of process production, as we have demonstrated. Here, a just-in-time material flow may be realized through the design of the production technology, leaving highly skilled, largely autonomous operators with the task of regulating that technology.

In technologically advanced production environments, industrial engineers may appreciate the insights from STD when dealing with aspects that are less developed in the literature on LP: worker motivation, QWL, and how to control non-routine activities by empowering employees. Combining the two concepts may aid organizations in exploiting opportunities for lean implementations that simultaneously increase technical performance and QWL.

\section{Declaration of Conflicting Interests}

The authors declared no potential conflicts of interest with respect to the research, authorship, and/or publication of this article. 


\section{Funding}

This work was supported by the Research Council of Norway.

\section{References}

Achterbergh, J., \& Vriens, D. (2010). Organizations: Social systems conducting experiments. Heidelberg: Springer Verlag. Adler, P.S., \& Cole, R.E. (1993). Designed for learning: A tale of two auto plants. Sloan Management Review, 34(3), 85-94.

Benders, J., Bal, M., \& Vermeerbergen, L. (2019). Structure Please; Continuous Improvement and Employee Consequences in a Dynamic Task Environment. Sustainability, 11, 5564. https://doi.org/10.3390/su11205564

Benders, J., \& Slomp, J. (2009). Struggling with solutions; a case study of using organisation concepts. International Journal of Production Research, 47(18), 5237-5243. https://doi.org/10.1080/00207540802070959

Benders, J., van Grinsven, M., \& Ingvaldsen, J. (2019). The persistence of management ideas: How framing keeps lean moving. In Sturdy, A., Heusinkveld, S., Reay, T., \& Strang, D. (Eds.), The Oxford handbook of management ideas, 271-285. Oxford: Oxford University Press. https://doi.org/10.1093/oxfordhb/9780198794219.013.4

Benders, J., \& Van Hootegem, G. (1999). Teams and their context: Moving the team discussion beyond existing dichotomies. Journal of Management Studies, 36(5), 609-628. http://doi.org/10.1111/1467-6486.00151

Benders, J., \& Verlaar, S. (2003). Lifting parts: Putting conceptual insights into practice. International Journal of Operations \& Production Management, 23(7), 757-774. https://doi.org/10.1108/01443570310481540

Berggren, C. (1992). Alternatives to lean production: Work organization in the Swedish auto industry. Ithaca: ILR Press.

Carter, B., Danford, A., Howcroft, D., Richardson, H., Smith, A., \& Taylor, P. (2017). Uncomfortable truthsTeamworking under lean in the UK. The International Journal of Human Resource Management, 28(3), 449-467. https://doi.org/10.1080/09585192.2015.1111251

Cherns, A. (1976). The Principles of Sociotechnical Design. Human Relations, 29(8), 783-792. https://doi.org/10.1177/001872677602900806

Christis, J., \& Soepenberg, E. (2016). Lowlands socio-technical design theory and lean production. In Mohr, B.J., \& van Amelsvoort, P. (Eds.), Co-creating humane and innovative organizations (303-325). Portland, ME: Global STS-D Network Press.

Cocca, P., Marciano, F., Alberti, M., \& Schiavini, D. (2018). Leanness measurement methods in manufacturing organisations: A systematic review. International Journal of Production Research, 57(15-16), 5103-5118. https://doi.org/10.1080/00207543.2018.1521016

Dabhilkar, M., \& Åhlström, P. (2013). Converging production models: The STS versus lean production debate revisited. International Journal of Operations \& Production Management, 33(8), 1019-1039. https://doi.org/10.1108/IJOPM-08-2012-0316

Dankbaar, B. (1997). Lean production: Denial, confirmation or extension of sociotechnical systems design? Human Relations, 50(5), 567-584. https://doi.org/10.1023/A:1016991803180

Delbridge, R., Lowe, J., \& Oliver, N. (2000). Shopfloor responsibilities under lean teamworking. Human Relations, 53(11), 1459-1479. https://doi.org/ 10.1177/00187267005311003

de Sitter, L.U., Hertog, J., \& Dankbaar, B. (1997). From complex organizations with simple jobs to simple organizations with complex jobs. Human Relations, 50(5), 497-534. https://doi.org/10.1023/A:1016987702271

de Treville, S., \& Antonakis, J. (2006). Could lean production job design be intrinsically motivating? Contextual, configurational, and levels-of-analysis issues. Journal of Operations Management, 24(2), 99-123.

https://doi.org/10.1016/j.jom.2005.04.001

Donaldson, L. (2001). The contingency theory of organizations. Thousand Oaks: Sage.

Dore, R. (1973). British factory-Japanese factory: The origins of national diversity in industrial relations. London: Allen \& Unwin. Fujimoto, T. (1999). The evolution of a manufacturing system at Toyota. New York: Oxford University Press.

Hasle, P. (2014). Lean production-An evaluation of the possibilities for an employee supportive lean practice. Human Factors and Ergonomics in Manufacturing \& Service Industries, 24(1), 40-53. https://doi.org/10.1002/hfm.20350

Hayes, R.H., \& Wheelwright, S.C. (1979). Link manufacturing process and product life cycles. Harvard Business Review, 57(1), 133-140. 
Hekneby, T., Ingvaldsen, J.A., \& Benders, J. (2020). Managing adoption by cultural development: Exploring the plant level effect of a 'Company Specific Production System'(XPS) in a Norwegian multinational company. Journal of Industrial Engineering and Management, 13(2), 402-416. https://doi.org/10.3926/jiem.3119

Herbst, P.G. (1976). Non-hierarchical forms of organization. Acta Sociologica, 19(1), 65-75. https://doi.org/10.1177/000169937601900106

Holweg, M. (2007). The genealogy of lean production. Journal of Operations Management, 25(2), 420-437. https://doi.org/10.1016/j.jom.2006.04.001

Hopp, W.J. (2018). Positive lean: Merging the science of efficiency with the psychology of work. International Journal of Production Research, 56(1-2), 398-413. https://doi.org/10.1080/00207543.2017.1387301

Hull, F.M., \& Collins, P.D. (1987). High-technology batch production systems: Woodward's missing type. Academy of Management Journal, 30(4), 786-797. https://doi.org/10.5465/256160

Huo, M.-L., \& Boxall, P. (2018). Are all aspects of lean production bad for workers? An analysis of how problemsolving demands affect employee well-being. Human Resource Management Journal, 28(4), 569-584. https://doi.org/10.1111/1748-8583.12204

Inamizu, N., Fukuzawa, M., Fujimoto, T., Shintaku, J., \& Suzuki, N. (2014). Group leaders and teamwork in the over-lean production system. Journal of Organizational Change Management, 27(2), 188-205. https://doi.org/10.1108/JOCM-08-2012-0122

Ingvaldsen, J.A. (2013). Democratic lean? Work systems in Norwegian Industry. PhD thesis. Norwegian University of Science and Technology (NTNU), Trondheim.

Ingvaldsen, J.A., \& Benders, J. (2016). Lost in translation? The role of supervisors in lean production. German Journal of Human Resource Management: Zeitschrift für Personalforscbung, 30(1), 35-52. https://doi.org/10.1177/2397002215625893

Karlsson, C., \& Åhlström, P. (1996). Assessing changes towards lean production. International Journal of Operations \& Production Management, 16(2), 24-41. https://doi.org/10.1108/01443579610109820

Kern, H., \& Schumann, M. (1992). New concepts of production and the emergence of the systems controller. In Adler, P.S. (Ed.), Technology and the future of work (111-142). New York: Oxford University Press.

Krafcik, J.F. (1988). Triumph of the lean production system. MIT Sloan Management Review, 30(1), 41-52.

Leite, H., Radnor, Z., \& Bateman, N. (2020). Meaningful inhibitors of the lean journey: a systematic review and categorisation of over 20 years of literature. Production Planning \& Control.

https://doi.org/10.1080/09537287.2020.1823511

Liker, J.K. (2004). The Toyota Way. New York: McGraw-Hill.

Lowe, J., Delbridge, R., \& Oliver, N. (1997). High-performance manufacturing: Evidence from the automotive components industry. Organization Studies, 18(5), 783-798. https://doi.org/10.1177/017084069701800504

Marin-Garcia, J.A., \& Bonavia, T. (2015). Relationship between employee involvement and lean manufacturing and its effect on performance in a rigid continuous process industry. International Journal of Production Research, 53(11), 3260-3275. https://doi.org/10.1080/00207543.2014.975852

Mehta, V., \& Shah, H. (2005). Characteristics of a work organization from a lean perspective. Engineering Management Journal, 17(2), 14-20. https://doi.org/10.1080/10429247.2005.11415282

Mintzberg, H. (1980). Structure in 5's: A synthesis of the research on organization design. Management Science, 26(3), 322-341. https://doi.org/10.1287/mnsc.26.3.322

Mohr, B.J., \& van Amelsvoort, P. (2016). Co-creating bumane and innovative organizations: Evolutions in the practice of socio-technical system design. Portland, ME: Global STS-D Network Press.

Neirotti, P. (2020). Work intensification and employee involvement in lean production: new light on a classic dilemma. The International Journal of Human Resource Management, 31(15), 1958-1983. https://doi.org/10.1080/09585192.2018.1424016

Netland, T.H. (2013). Exploring the phenomenon of company-specific production systems: One-best-way or own-best-way? International Journal of Production Research, 51(4), 1084-1097.

https://doi.org/10.1080/00207543.2012.676686

Netland, T.H., \& Powell, D.J. (Eds.). (2017). The Routledge companion to lean management. New York: Routledge. 
Nielsen, K.T., Møller, K.J., \& Koch, C. (1990). Japanese Inspired Production Systems and Working Conditions. Copenhagen: The Danish Technological Institute.

Niepce, W., \& Molleman, E. (1998). Work design issues in lean production from a sociotechnical systems perspective: Neo-Taylorism or the next step in sociotechnical design? Human Relations, 51(3), 259-287. https://doi.org/10.1023/A:1016992403973

Ohno, T. (1988). Toyota Production System: Beyond large-scale production. New York: Productivity Press.

Ortmann, G. (1995). Formen der Produktion: Organisation und Rekursivität. Opladen: Westdeutscher Verlag.

Oudhuis, M., \& Tengblad, S. (2020). The viability of the Scandinavian work-life model and the impact of lean production: The case of Scania. Economic and Industrial Democracy. https://doi.org/10.1177/0143831x20939137

Pil, F.K., \& Fujimoto, T. (2007). Lean and reflective production: The dynamic nature of production models. International Journal of Production Research, 45(16), 3741-3761. https://doi.org/10.1080/00207540701223659

Procter, S., \& Radnor, Z. (2017). Teamworking and Lean revisited: A reply to Carter et al. The International Journal of Human Resource Management, 28(3), 468-480. https://doi.org/10.1080/09585192.2015.1111252

Safizadeh, M.H., Ritzman, L.P., Sharma, D., \& Wood, C. (1996). An empirical analysis of the product-process matrix. Management Science, 42(11), 1576-1591. https://doi.org/10.1287/mnsc.42.11.1576

Schonberger, R.J. (1982). Japanese manufacturing techniques: Nine bidden lessons in simplicity. New York: Simon and Schuster.

Schouteten, R., \& Benders, J. (2004). Lean production assessed by Karasek's job demand-job control model. Economic and Industrial Democracy, 25(3), 347-373. https://doi.org/10.1177/0143831x04044831

Shingo, S. (1981). A study of the Toyota Production System from an industrial engineering viewpoint. Tokyo: Japan Management Association.

Sorge, A. (1991). Strategic fit and the societal effect: Interpreting cross-national comparisons of technology, organization and human resources. Organization Studies, 12(2), 161-190. https://doi.org/10.1177/017084069101200201

Sousa, R., \& Voss, C.A. (2008). Contingency research in operations management practices. Journal of Operations Management, 26(6), 697-713. https://doi.org/10.1016/j.jom.2008.06.001

Spring, M., \& Unterhitzenberger, C. (2020). The role of operations managers in translating management ideas and practices between firms. Production Planning \& Control, 1-16. https://doi.org/10.1080/09537287.2020.1823025

Sugimori, Y., Kusunoki, K., Cho, F., \& Uchikawa, S. (1977). Toyota production system and Kanban system Materialization of just-in-time and respect-for-human system. International Journal of Production Research, 15(6), 553-564. https://doi.org/10.1080/00207547708943149

Womack, J.P., \& Jones, D.T. (1996). Lean thinking: Banish waste and create wealth in your corporation. New York: Simon \& Schuster.

Womack, J.P., Jones, D.T., \& Roos, D. (1990). The machine that changed the world. New York: Simon \& Schuster.

Woodward, J. (1980). Industrial organization: Theory and practice. Oxford: Oxford University Press.

Yin, R.K. (2009). Case study research: Design and methods. Thousand Oaks: Sage.

Young, S.M. (1992). A framework for successful adoption and performance of Japanese manufacturing practices in the United States. The Academy of Management Review, 17(4), 677-700. https://doi.org/10.2307/258804

Journal of Industrial Engineering and Management, 2021 (www.jiem.org)

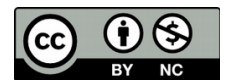

Article's contents are provided on an Attribution-Non Commercial 4.0 Creative commons International License. Readers are allowed to copy, distribute and communicate article's contents, provided the author's and Journal of Industrial Engineering and Management's names are included. It must not be used for commercial purposes. To see the complete license contents, please visit https://creativecommons.org/licenses/by-nc/4.0/. 